\title{
PROMOTION OF ORGANIC FOOD IN SERBIA: IMPLICATIONS FROM ORGANIC FOOD CONSUMERS' PROFILE RESEARCH
}

\author{
Ines Đokić ${ }^{1}$, Nenad Đokić ${ }^{2}$, Nataša Pavlovic ${ }^{3}$, Ružica Kovač Žnideršićc ${ }^{4}$
}

\begin{abstract}
Summary
The article presents the results of the research of organic food frequency of consumption (in general), conducted in Serbia in June 2013 (n=300). Respondents were classified into low-frequent organic food consumers 'segment and high-frequent organic food consumers' segment. Socio-demographic characteristics of respondents were also investigated, thus allowing comparing two segments regarding consumers' profile. The organic food highfrequent consumers' segment consisted of more women, more educated people, more married respondents and respondents living with children and having larger households, as well as of consumers with higher self-assessed household income in comparison to organic food low-frequent consumers'segment. Having in mind the results of the research and the level of domestic market development when choosing which segment to target, as well as starting from understanding promotion in the context of integrated marketing communication and the means-end approach to consumer behavior, recommendations for organic food promotion were given.
\end{abstract}

Key words: organic food, market segmentation, marketing management, promotion, Serbia.

JEL: M30, M31, M37

\section{Introduction}

Despite having satisfying natural preconditions for growing organic food (Vlahović, Štrbac, 2007), the production of organic food and development of this food market in Serbia can be described as modest (März et al., 2012) and there are contradictory prognosis regarding future level of acceptance of organic food by domestic consumers. On one hand, there are

1 Ines K. Đokić, M.Sc., Teaching Assistant, University of Novi Sad, Faculty of Economics Subotica, Segedinski put no. 9-11, 24000 Subotica, Serbia, Phone: +381 24628 133, E-mail: $\underline{\text { mines@ef.uns.ac.rs }}$

2 Nenad S. Đokić, M.Sc., Teaching Assistant, University of Novi Sad, Faculty of Economics Subotica, Segedinski put no. 9-11, 24000 Subotica, Serbia, Phone: +381 24628 217, E-mail: djokicn@ef.uns.ac.rs

3 Nataša Đ. Pavlović, M.A., Turistic Organization of Vojvodina, Bulevar Mihajla Pupina no. 6, 21000 Novi Sad, Serbia, Phone: +381 21452 910, E-mail: nts.pavlovic@gmail.com

4 Ružica S. Kovač Pečkai Žnideršić, Ph.D., Full Professor, University of Novi Sad, Faculty of Economics Subotica, Segedinski put no. 9-11, 24000 Subotica, Serbia, Phone: +381 24628134 , E-mail: znikor@ef.uns.ac.rs

EP 2014 (61) 4 (837-849) 
authors who believe it is not to be expected organic food to be increasingly accepted by domestic consumers (Maslac, 2009; März et al., 2012), explaining that their thesis can be supported by the facts that Serbian GDP per capita increased for two times in period from 1999 to 2009 while food prices increased for nine times in the same period, as well as by the facts that average monthly income in Serbia is less than 400 USD and consumers are unwilling to pay premium price of 30 to $40 \%$ for organic food. On the other hand, there are authors who point out that it can be expected that organic food will be mostly bought by more educated consumers and consumers taking care about their own health and consequently this food will become part of daily food consumption, while its premium price will not present barrier for it (Renko et al., 2011).

Nevertheless, domestic organic food consumers are crucial as first impulse motivating domestic farmers to start their organic food production (Kočić Vugdelija et al., 2011). That is why it was needed to research domestic organic food consumers' profile in order to be able to identify effective approaches for targeting them. The importance of this question can be analyzed from the perspective of foreign producers and importers of organic food to Serbia as well, since a number of organic food categories are being imported to domestic market (März et al., 2012).

This paper will present the results of the research of self-reported frequency of consumption of organic food in Serbia followed by data regarding socio-demographic characteristics of respondents, from which low-frequent and high-frequent organic food consumers' segments were derived and their socio-demographic profile described. After researching profile of lowfrequent and high-frequent organic food consumers (which belongs to strategic marketing), implications on organic food promotion (belonging to tactical marketing i.e. marketing mix) will be given. Considering the significance of promotion of organic food on emerging markets (Davčik, 2004; Vlahović et al., 2011), as well as having in mind that promotion is in this paper understood in the context of integrated marketing communication and the meansend approach to consumer behavior, given recommendations can be significant for marketing mix as whole.

\section{Theoretical background, literature review and hypotheses development}

The steps in marketing management process connecting consumers' profile research (i.e. market segmentation research) and promotion as marketing mix instrument were used as theoretical background of this paper. Namely, Kotler (2007) lists steps in marketing management process: marketing research, strategic marketing (which includes market segmentation, targeting and positioning) and tactical marketing (i.e. creating marketing mix, its implementation and control).

Market segmentation can be defined as the identification of individuals or organizations with similar characteristics, with significant implications for determining marketing strategy (Jobber, Fahy, 2006). Considering final consumer markets, criteria grouped into geographic, demographic, psychographic and behavioral can be used as the basis for segmentation (Kotler, Keller, 2006). In a number of organic food market segmentation 
researches behavioral criteria are used as basis for segmentation, followed with the use of socio-demographic criteria as descriptors.

However, there can be identified contradictions regarding the existence and/or direction of different socio-demographic criteria influence when profiling organic food market segments (Bonti-Ankomah, Yiridoe, 2006; Hughner et al., 2007). For example, some researches point out women being more in favor of concept of organic food (Koivisto Hursti, Magnusson, 2003; Lockie et al., 2004; Arbindra et al., 2005; Padel, Foster, 2005) while other researches find no significance of gender when describing organic consumers' profile (Loureiro, Hine, 2002; Sandalidou et al., 2002; Gracia, de Magistris, 2007; Zepeda, Li, 2007). Some researches emphasize older people being organic food consumers (Sandalidou et al., 2002), some point out contrary (Arbindra et al., 2005; Zepeda, Li, 2007; Cicia et al., 2002; Loureiro, Hine, 2002), while some state that age has no relevance when describing organic food consumers' profile (Koivisto Hursti, Magnusson, 2003; Lockie et al., 2004; Gracia, de Magistris, 2007). A number of researches describe organic food consumers as more educated (Zepeda, Li, 2007; Cicia et al., 2002; Sandalidou et al., 2002; Loureiro, Hine, 2002), while some researches point out consumers' education having no significance for organic food consumption (Koivisto Hursti, Magnusson, 2003; Arbindra et al., 2005). Regarding socio-demographic profile of organic food consumers, in some researches positive influence of higher income is emphasized (Loureiro, Hine, 2002; Sandalidou et al., 2002; Arbindra et al., 2005; Gracia, de Magistris, 2007; Stolz et al., 2011) while according to others, consumers' income is not affecting their organic food consumption (Lockie et al., 2004; Zepeda, Li, 2007). There is no single conclusion about the existence and/or direction of influence of family life-cycles phase, marital status, household size and presence of children in family in describing organic food consumers' profile as well (Loureiro et al., 2001; Cicia et al., 2002; Loureiro, Hine, 2002; Sandalidou et al., 2002; Padel, Foster, 2005; Zepeda, Li, 2007; Stolz et al., 2011).

There are attempts to explain reasons of such contradictions among results of different researches of organic consumers (Bonti-Ankomah, Yiridoe, 2006), but the recommendations for overcoming these problems do not include omitting of the use of socio-demographic variables in these researches. Consumers' socio-demographic characteristics are also implicitly present in the behavior theories related to consumers' food choices: the Theory of Reasoned Action and its later modification the Theory of Planned Behavior Theory (Aertsens et al., 2009).

Some researchers conducted in Serbia until now point out that organic food consumers mostly were at that moment and would be in the future high educated people (Maslac, 2009; Renko et al., 2011), young people (Maslac, 2009; Renko et al., 2011) and women (Maslac, 2009).

Having in mind the modest level of domestic organic food market development and the cited results of researches regarding socio-demographic variables influences in describing organic food consumers profile, as well as starting from segmenting domestic organic food consumers into high-frequent (who consume organic food at least once a week) and lowfrequent consumers, following hypothesis have been proposed: 
- H1: There can be identified high-frequent organic food consumers' segment in Serbia.

- H2: High-frequent organic food consumers' segment is statistically significantly different from low-frequent organic consumers' segment by consisting of larger percent of women.

- H3: High-frequent organic food consumers' segment is statistically significantly different from low-frequent organic consumers' segment by consisting of consumers with lower mean age (younger consumers).

- H4: High-frequent organic food consumers' segment is statistically significantly different from low-frequent organic consumers' segment by consisting of consumers with higher mean rank of education (more high educated people).

- H5: High-frequent organic food consumers' segment is statistically significantly different from low-frequent organic consumers' segment by consisting of larger percent of married respondents.

- H6: High-frequent organic food consumers' segment is statistically significantly different from low-frequent organic consumers' segment by consisting of larger percent of consumers with children in their families.

- H7: High-frequent organic food consumers' segment is statistically significantly different from low-frequent organic consumers' segment by consisting of consumers with higher mean of their household size (consumers with larger households).

- H8: High-frequent organic food consumers' segment is statistically significantly different from low-frequent organic consumers' segment by consisting of consumers with higher mean of self-assessed household income (consumers with higher income).

Continuing description of marketing management process' steps, it should be emphasized that after deciding which of the identified segments to target and how to take a distinctive position in consumers' minds, marketing mix (product, price, place and promotion) is being created, implemented and controlled (Kotler, 2007). Hereby, promotion can be understood in the context of integrated marketing communication concept presenting ,theoretical perspective that advocates a high level of communication interaction between a brand's marketers and its consumers coupled with a high degree of message consistency across a brand's entire marketing mix, ranging from the product itself to all marketing communications media" (McGrath, 2010). At the same time, it is possible to consider promotion as well as whole process of consumer behavior according to the means-end approach meaning consumers are not interested in products per se, but are interested in them regarding the way the product helps them attain their life values (Reynolds, Olson, 2001).

Since domestic organic food market is in early stages of development, in this paper promotion was suggested in function of targeting high-frequent consumers' and positioning in their minds, considering theoretical background as described above. 


\section{Questionnaire}

There were two parts of the questionnaire. At the beginning, socio-demographic characteristics of respondents were investigated: gender, age, education, marital status, presence of children in family, the size of the household and self-assessed household income (from 1 - the lowest, to 5 - the highest mark).

The second part of the questionnaire was designed in order to collect data regarding selfreported frequency of consumption of organic food. It was chosen to use organic food in general and not by categories since it is not widely present at domestic food market. The self-reported frequency of consumption was measured by seven-point Likert scale, with meanings: level 1 - never, level 2 - once in several months, level 3 - once in several weeks, level 4 - once a week, level 5 - several times a week, level 6 - every day, level 7 - several times a day.

It took from up to 15 minutes for the respondents to fill in the questionnaire.

\section{Interviewees}

The respondents were 20 to 65 years old. There were 300 respondents interviewed in several larger towns of Serbia, in June 2013. The respondents were approached near green markets, large shopping centers and school/university centers attempting to reach average food consumer in Serbia.

In the sample there were $34.0 \%$ of male and $66.0 \%$ of female. The average respondent was 37.14 years old (standard deviation 12.575). Considering education, $46.0 \%$ of respondents had finished secondary school, $19.0 \%$ of respondents were attending college or faculty and $35.0 \%$ had finished college or faculty. Regarding marital status, $46.7 \%$ of respondents were married and $53.3 \%$ were single, while regarding children, there were $52.3 \%$ of respondents who had not lived in the same household with his/her child/children, while $47.7 \%$ had. The average household size was 3 (standard deviation 1.268). Regarding household income, the average self- assessment of it (using 1 as the lowest and 5 as the highest mark) was 2.76 (standard deviation 1.091).

\section{Data analysis}

Data analysis was performed by using MS Office Excel and SPSS.

After investigating the self-reported frequencies of consumption of organic food, the respondents were divided into low- and high-frequent consumers in following manner: to low-frequent consumers segment were classified respondents rating they consume organic food never, once in several months or once in several weeks (1,2 and 3), while to highfrequent consumers segment were classified respondents rating they consume it once a week, several times a week, every day or several times a day $(4,5,6$ and 7).

Analysis was also conducted for investigating whether low- and high- frequent consumers segments were statistically significantly different regarding chosen socio-demographic 
characteristics. Pearson Chi-Square test was used regarding gender, marital status and the presence of children in family. Independent samples T-test was used considering age, household size and self-assessed household income. Mann-Whitney U test was used regarding respondents' education.

\section{Results}

The results regarding self-reported frequency of consumption of organic food and the size of consumers' segments derived from these data are given in Table 1.

Table 1. Self-reported frequency of consumption of organic food and consumer segments

\begin{tabular}{|c|c|c|c|c|}
\hline $\begin{array}{l}\text { Self-reported frequency of } \\
\text { consumption of organic food }\end{array}$ & Frequency & $\%$ & Consumer segments & $\%$ \\
\hline never & 118 & 39.3 & \multirow{3}{*}{$\begin{array}{l}\text { Low-frequent organic food } \\
\text { consumers }\end{array}$} & \multirow{3}{*}{71.7} \\
\hline once in several months & 43 & 14.3 & & \\
\hline once in several weeks & 54 & 18.0 & & \\
\hline once a week & 42 & 14.0 & \multirow{4}{*}{$\begin{array}{l}\text { High-frequent organic food } \\
\text { consumers }\end{array}$} & \multirow{4}{*}{28.3} \\
\hline several times a week & 35 & 11.7 & & \\
\hline every day & 7 & 2.3 & & \\
\hline several times a day & 1 & 0.3 & & \\
\hline Total & 300 & 100.0 & & 100.0 \\
\hline
\end{tabular}

Source: Authors' research.

Descriptive statistics regarding two segments' socio-demographic characteristics are given in Table 2.

Table 2. Socio-demographic characteristics of two segments

\begin{tabular}{|c|c|c|c|c|}
\hline \multicolumn{3}{|c|}{ Socio-demographic characteristics } & \multirow{2}{*}{$\begin{array}{c}\begin{array}{c}\text { Low-frequent } \\
\text { organic food } \\
\text { consumers }\end{array} \\
39.10 \\
\end{array}$} & \multirow{2}{*}{$\begin{array}{c}\begin{array}{c}\text { High-frequent } \\
\text { organic food } \\
\text { consumers }\end{array} \\
21.20 \\
\end{array}$} \\
\hline ond & male & $\%$ & & \\
\hline gender & female & $\%$ & 60.90 & 78.80 \\
\hline \multicolumn{2}{|c|}{ Age } & mean (SD) & $37.53(12.868)$ & $36.14(11.815)$ \\
\hline \multirow{2}{*}{ marital status } & single & $\%$ & 60.90 & 34.10 \\
\hline & married & $\%$ & 39.10 & 65.90 \\
\hline \multirow{2}{*}{$\begin{array}{l}\text { presence of } \\
\text { children in } \\
\text { family }\end{array}$} & $\begin{array}{c}\text { family with no } \\
\text { children }\end{array}$ & $\%$ & 60.00 & 32.90 \\
\hline & $\begin{array}{l}\text { family with } \\
\text { children }\end{array}$ & $\%$ & 40.00 & 67.10 \\
\hline \multicolumn{2}{|l|}{ household size } & mean (SD) & $2.74(1.217)$ & $3.64(1.174)$ \\
\hline \multicolumn{2}{|l|}{ education } & median (mean rank) & $2(143.72)$ & $2(168.41)$ \\
\hline \multicolumn{2}{|c|}{ self-assessed household income } & mean (SD) & $2.65(1.057)$ & $3.06(1.127)$ \\
\hline
\end{tabular}

Source: Authors' research.

The results of Pearson Chi-Square test for gender are: $\chi^{2}(\mathrm{df}=1)=8.691, \mathrm{p}=0.003<0.05$; for marital status are: $\chi^{2}(\mathrm{df}=1)=17.596, \mathrm{p}=0.000<0.05$; and for presence of children in family are: $\chi^{2}(\mathrm{df}=1)=17.880, \mathrm{p}=0.000<0.05$. 
The results of the Independent samples T-test for age are: $\mathrm{t}(\mathrm{df}=298)=0.862, \mathrm{p}=0.389>0.05$; for household size are: $\mathrm{t}(\mathrm{df}=298)=-5.772, \mathrm{p}=0.000<0.05$; and for self-assessed household income are: $\mathrm{t}(\mathrm{df}=298)=-2.987, \mathrm{p}=0.003<0.05$.

The results of Mann-Whitney U test, that was used regarding differences in respondents' education between low-frequent organic food consumers $(M d=2, n=215)$ and high-frequent organic food consumers $(\mathrm{Md}=2, \mathrm{n}=85)$, are: $\mathrm{Z}=-2.435, \mathrm{p}=0,015<0.05$.

\section{Discussion}

The results of the research confirmed the first hypothesis that in Serbia there can be identified respondents that consume organic food at least once a week (high-frequent organic food consumers' segment). This segment refers to $28.3 \%$ of all the respondents. In general population, this could be even smaller percent since the sample in this research is not fully representative (more educated and younger respondents were more willing to participate in the research). This result is in accordance to other researches' results describing organic food market development in Serbia as modest (März et al., 2012). Some future researches could, in order to get deeper understanding of potential of organic food market in Serbia, besides examining actual organic food consumption, include studying preferences for organic food and obstacles for transforming these preferences into actual consumption as well.

Starting from behavioral criteria (self-reported frequency of consumption of organic food measuring organic food actual consumption) as basis for segmentation, two consumers' segments were identified (low-frequent organic food consumers and high-frequent organic food consumers) and socio-demographic criteria were used as descriptors of these segments, as it is often performed in organic food consumers' researches. Statistical tests confirmed all hypotheses except H3 regarding high-frequent organic food consumers' segment being statistically significantly different from low-frequent organic consumers' segment by consisting of consumers with lower mean age (younger consumers). Although, average age of high-frequent organic consumers is lower than of the low-frequent organic consumers, the statistically significant difference does not exist. This is in accordance to results of some researchers conducted abroad (Koivisto Hursti, Magnusson, 2003; Lockie et al., 2004; Gracia, de Magistris, 2007). However, the results are not fully in accordance to previous researches conducted in Serbia emphasizing young people as organic food consumers (Maslac, 2009; Renko et al., 2011). There can be two explanations regarding such differences. Firstly, these other researches were not focusing only at actual organic food consumption at the time when conducted but also at potential of organic food market. Secondly, in this research high-frequent organic food consumers are younger than lowfrequent organic food consumers, but the lack of statistical significance for that difference could be due to the structure of the sample.

As already stated, all other hypotheses were confirmed and statistically significant differences between two segments regarding other socio-demographic variables were established. This implies that there is larger percent of women in high-frequent organic food consumers' segment than in low-frequent organic food consumers' segment. It is in accordance to some 
researches in other countries which point out women being more in favor of concept of organic food (Koivisto Hursti, Magnusson, 2003; Lockie et al., 2004; Arbindra et al., 2005; Padel, Foster, 2005) and with one previous research in our country (Maslac, 2009). The results also suggest that high-frequent organic food consumers are more educated than lowfrequent organic food consumers, what is consistent with previous researches conducted in Serbia (Maslac, 2009; Renko et al., 2011), as well as with researches conducted in other parts of the world (Zepeda, Li, 2007; Cicia et al., 2002; Sandalidou et al., 2002; Loureiro, Hine, 2002). High-frequent organic food consumers have also higher income (at least they assess their income as higher) in comparison to low-frequent organic food consumers. This is in accordance to results of the researches conducted abroad emphasizing positive influence of higher income on organic food consumption (Loureiro, Hine, 2002; Sandalidou et al., 2002; Arbindra et al., 2005; Gracia, de Magistris, 2007; Stolz et al., 2011).

There is larger percent of high-frequent organic food consumers that are married and living with children in their families in comparison to low-frequent organic food consumers, and they live in larger households as well. This also resembles to the results of some of the researches conducted in other countries (Loureiro et al., 2001; Sandalidou et al., 2002; Cicia et al., 2002; Padel, Foster, 2005; Stolz et al., 2011).

Generally, it can be concluded that organic food high-frequent consumers' segment consists of more women, educated people, married respondents and respondents living with children and having larger households, as well as of consumers with higher self-assessed household income in comparison to organic food low-frequent consumers' segment.

\section{Implications of the results of the research on organic food promotion}

Having in mind organic food high-frequent consumers' profile and perception of organic food in the context of potential beneficial influence on health as well as perception that by buying such food consumers help in preserving the nature and have possibility to live according to the nature, which are in accordance to basic principles of organic agriculture, promotion mix will be suggested. It was chosen to target high-frequent organic food consumers considering domestic organic food market being in early stages of development and expecting, according to experience of other countries which were in this phase before, that main impulse for additional organic food demand would come from these consumers.

Advertising should show nature in all its beauty when promoting such products, while the appearance of people in these products' commercials should suggest health, easiness of movement and peace. Children should also take place in such commercials in order to allow suggesting connection of something the most valuable any person has - the family with the pure and strong nature. The advertisement can be performed before, during or after TV programs watched usually by married people with children. For example, the advertisement can be performed in periods before programs about nature broadcasted mostly on weekend day's afternoon. It can also be emitted before or after playing intermezzo program on domestic televisions usually showing natural beauties and playing classical music. Advertisement can also take place before programs speaking about giving birth 
or raising babies. The billboards could be placed by the roads to maternity hospitals or hospitals in general, with clear indications where these products can be bought.

Sales promotions of organic food could take place at supermarkets in ambient arranged to remind on nature or green market, with the message, especially addressed to married couples with children, that when buying organic food it is not necessary to know the seller for trusting the quality since these products and their production process are natural per se. Marketing public relations should provide journalists information about organic food benefits. Production process should be filmed and shown to journalists or even to broader audience with emphasizing the absence of unhealthy artificial substances in such food and it should be offered them to taste. Hereby, journals (as well as TV programs) should deliver scientific facts regarding organic food to targeted audience since consisting of more educated people and it should be explained to them that by paying premium price of organic food they get the value for their money. Sponsorships of activities such as providing resources for buying incubators for maternity hospitals or apparatus for diagnosis for hospitals are also recommended. Products' visual identity should suggest the freshness and cleanness of ingredients and their distribution could rely on natural products' stores or on separately marked corners of supermarkets. Development of such a promotion mix will be even more important when greater offer of these products will be available and when other actors of the supply chain, more powerful than individual farmers, participate in supply more intensively.

\section{Conclusions}

This paper demonstrates the connection between steps in marketing management process: consumers' profile research (i.e. market segmentation research), belonging to strategic marketing, and creating promotion mix (as marketing mix instrument), that belongs to tactical part of marketing. That connection is demonstrated by a number of recommendations stemming from the conducted research referring to organic food, for which promotion is crucial on emerging markets as Serbian is, and which is additionally important because of domestic organic food consumers being a first impulse motivating domestic farmers to start their organic food production.

After the review of the literature and formulating hypotheses, the research was conducted with 300 respondents interviewed in several larger towns of Serbia, in June 2013. The actual food consumption was measured by self-reported frequency of organic food consumption and additional socio-demographic characteristics of respondents were investigated: gender, age, education, marital status, presence of children in family, the size of the household and self-assessed household income. Starting from behavioral criteria (self-reported frequency of organic food consumption) as basis for segmentation, two consumers' segments were identified (high-frequent organic food consumers, consuming organic food at least once a week, and low-frequent organic food consumers). At the same time, socio-demographic criteria were used as descriptors of these segments, as it is often performed in organic food consumers' researches. 
The results point out that in Serbia there can be identified high-frequent organic food consumers' segment (28.3\% of all the respondents in this sample that is not fully representative). Generally, organic food high-frequent consumers' segment consists of more women, more educated people, more married respondents and respondents living with children and having larger households, as well as of consumers with higher self-assessed household income in comparison to organic food low-frequent consumers' segment.

After performing market segmentation, implications for promotion were considered. It was chosen to target high-frequent organic food consumers having in mind domestic organic food market being in early stages of development and expecting, according to the experience of other countries which were in this phase before, that main impulse for additional organic food demand would come from these consumers. Beside these consumers' profile, perception of organic food in context of potential beneficial influence on health as well as perception that by buying such food consumers help in preserving the nature and have possibility to live according to the nature, which are in accordance to basic principles of organic agriculture, were considered when promotion mix was suggested.

Future researches could, in order to get deeper understanding of potential of organic food market in Serbia, besides examining actual organic food consumption, include studying preferences for organic food and obstacles for transforming these preferences into actual consumption as well. They could also be product specific (this research was related to organic food in general due to early stages of this food domestic market development) and conducted on larger and more representative samples. However, according to the authors' opinion that does not question the importance of tendencies and recommendations stemming from this research.

\section{Literature}

1. Aertsens, J., Verbeke, W., Mondelaers, K., Van Huylenbroeck, G. (2009): Personal determinants of organic food consumption: A review, British Food Journal, vol. 111, no. 10, pp. 1140-1167.

2. Arbindra, P. R., Moon, W., Balasubramanian, S. (2005): Agro-biotechnology and organic food purchase in the United Kingdom, British Food Journal, vol. 107, no. 2, pp. 84-97.

3. Bonti-Ankomah, S., Yiridoe, E. K. (2006): Organic and Conventional Food: A Literature Review of the Economics of Consumer Perceptions and Preferences, Organic Agriculture Centre of Canada, Nova Scotia, available at: www.organicagcentre.ca/Docs/BONTI\%20 \&\%20YIRIDOE $\% 20$ April $\% 2028 \% 202006 \% 20$ Final.pdf

4. Cicia, G., Del Giudice, T., Scarpa, R. (2002): Consumers'perception of quality in organic food: A random utility model under preference heterogeneity and choice correlation from rank-orderings, British Food Journal, vol. 104, no. 3, 4, 5, pp. 200-213.

5. Davčik, N. (2004): Marketing strategija proizvoda u industriji hrane-ekološki pristup, Ecologica, vol. 11, no. 43, pp. 25-32. 
6. Gracia, A., de Magistris, T. (2007): Organic food product purchase behaviour: A pilot study for urban consumers in the South of Italy, Spanish Journal of Agricultural Research, vol. 5, no. 4, pp. 439-451.

7. Hughner, R. S., McDonagh, P., Prothero, A., Shultz, C. J., Stanton, J. (2007): Who are organic food consumers? A compilation and review of why people purchase organic food, Journal of Consumer Behaviour, vol. 6, no. 2, 3, pp. 94-110.

8. Jobber, D., Fahy, J. (2006): Osnovi marketinga, Data status, Beograd.

9. Kočić Vugdelija, V., Berber, N., Đokić, N. (2011): Upravljanje procesom proizvodnje $i$ mogućnosti distribucije organskih poljoprivrednih proizvoda, Proceedings of the scientific conference Contemporary trends in European economy: Implications for Serbia, Novi Sad, $27^{\text {th }}$ October, 2011, Novi Sad, Higher School of Professional Business Studies.

10. Koivisto Hursti, U. K., Magnusson, M. K. (2003): Consumer perceptions of genetically modified and organic foods: What kind of knowledge matters?, Appetite, vol. 41, no. 2, pp. 207-209.

11. Kotler, P. (2007): Kako kreirati, ovladati i dominirati tržištem, Asee books, Novi Sad.

12. Kotler, P., Keller, K. L. (2006): Marketing menadžment, Data status, Beograd.

13. Lockie, S., Lyons, K., Lawrence, G., Grice, J. (2004): Choosing organics: A path analysis offactors underlying the selection of organic food among Australian consumers, Appetite, vol. 43 , no. 2 , pp. 135-146.

14. Loureiro, M. L., McCluskey, J. J., Mittlehammer, R. C. (2001): Assessing consumer preferences for organic, eco-labeled, and regular apples, Journal of Agricultural and Resource Economics, vol. 26, no. 2, pp. 404-416.

15. Loureiro, M., Hine, S. (2002): Discovering niche markets: A comparison of consumer willingness to pay for a local (Colorado-grown), organic, and GMO-free product, Journal of Agricultural and Applied Economics, vol. 34, no. 3, pp. 477-487.

16. März, U., Stolz, T., Kalentić, M., Stefanović, E. (2012): Organic agriculture in Serbia 2012-At a Glance, National Association „Serbia Organica“, Belgrade.

17. Maslac, T. (2009): Organic Agriculture in Serbia, USDA Foreign Agricultural Service, Belgrade, available at: http://gain.fas.usda.gov/Recent $\% 20$ GAIN\%20Publications/ Organic\%20Agriculture\%20in\%20Serbia Belgrade Serbia 6-8-2009.pdf

18. McGrath, J. M. (2010): Using Means-End Analysis to Test Integrated Marketing Communications Effects, Journal of Promotion Management, vol. 16, pp. 361-387.

19. Padel, S., Foster, C. (2005): Exploring the gap between attitudes and behaviour: Understanding why consumers buy or do not buy organic food, British Food Journal, vol. 107, no. 8, pp. 606-625.

20. Renko, N., Butigan, R., Renko, S., Vuletic, A., Barjolle, D., Zaouche-Laniau, M., Schaer, B., Berner, N., Eynaudi, D., Markovic, D., Tomic, L., Kendrovski, V., Bajic, 
B., Scepanovic, S., Stojanovic, Z., Stoikovic, D., Gligoric, M., Popovic, S., Klopcic, M., Pohar, J. (2011): Market data, market trends and consumer behaviour report for organic products in the WBC, University of Zagreb Croatia and Ecozept GbR, available at: www.focus-balkans.org/res/files/upload/file/DL7\%202 Market\%20 data $\% 20$ market $\% 20$ trends $\% 20$ and $\% 20$ consumer $\% 20$ behaviour $\% 20$ report $\% 20$ for $\% 20$ organic $\% 20$ products $\% 20 \mathrm{in} \% 20$ the $\% 20 \mathrm{WBC}$ final.pdf

21. Reynolds, T. J., Olson, J. C. (2001): Understanding Consumer Decision Making: The Means-end Approach to Marketing and Advertising Strategy, Lawrence Erlbaum Associates, Mahwah, NJ.

22. Sandalidou, E., Baourakis, G., Siskos, Y. (2002): Customers'perspectives on the quality of organic olive oil in Greece: A satisfaction evaluation approach, British Food Journal, vol. 104, no. 3,4,5, pp. 391-406.

23. Stolz, H., Stolze, M., Janssen, M., Hamm, U. (2011): Preferences and determinants for organic, conventional and conventional-plus products - The case of occasional organic consumers, Food Quality and Preference, vol. 22, no. 8, pp. 772-779.

24. Vlahović, B., Radojević, V., Živanić, I. (2011): Istraživanje stavova potrošača o potrošnji organske hrane u Srbiji, Ekonomika poljoprivrede, vol. 58, no. 3, pp. 443-456.

25. Vlahović, B., Štrbac, M. (2007): Osnovne karakteristike tržišta i marketinga proizvoda organske poljoprivrede, Ekonomika poljoprivrede, vol. 54, no. 2, pp. 131-147.

26. Zepeda, L., Li, J. (2007): Characteristics of organic food shoppers, Journal of Agricultural and Applied Economics, vol. 39, no. 1, pp. 17-28. 


\title{
PROMOCIJA ORGANSKE HRANE U SRBIJI: IMPLIKACIJE ISTRAŽIVANJA PROFILA POTROŠAČA ORGANSKE HRANE
}

\author{
Ines Đokič ${ }^{5}$, Nenad Đokič́, Nataša Pavlovič ${ }^{7}$, Ružica Kovač Žnideršič ${ }^{8}$
}

\begin{abstract}
Sažetak
Članak prikazuje rezultate istraživanja frekvencije potrošnje organske hrane (uopšte uzev), sprovedenog u Republici Srbiji u junu 2013 (n=300). Ispitanici su klasifikovani u segment potrošača koji retko konzumiraju organsku hranu i segment potrošača koji često konzumiraju organsku hranu. Istražene su i sociodemografske karakteristike ispitanika što je omogućilo poređenje profila potrošača dva segmenta. Segment potrošača koji često konzumiraju organsku hranu sastoji se od većeg udela žena, ispitanika u braku, ispitanika koji žive u porodici sa decom, a ti ispitanici su takođe i obrazovaniji, žive u većim domaćinstvima i daju višu ocenu prihodu domaćinstva. Imajući u vidu rezultate istraživanja kao i nivo razvijenosti domaćeg tržišta pri odabiru koji segment targetirati, kao i polazeći od razumevanja promocije ukontekstu integrisanih marketing komunikacija i sredstvo-cilj pristupa ponašanju potrošača, date su preporuke za promociju organske hrane.
\end{abstract}

Ključne reči: organska hrana, segmentacija tržišta, marketing menadžment, promocija, Srbija.

5 Ines K. Đokić, M.Sc., asistent, Univerzitet u Novom Sadu, Ekonomski fakultet u Subotici, Segedinski put 9-11, 24000 Subotica, Srbija, Telefon: +381 24628 133, E-mail: mines@ef.uns.ac.rs

6 Nenad S. Đokić, M.Sc., asistent, Univerzitet u Novom Sadu, Ekonomski fakultet u Subotici, Segedinski put 9-11, 24000 Subotica, Srbija, Telefon: +381 24628 217, E-mail: djokicn@ef.uns.ac.rs

7 Nataša Đ. Pavlović, magistar, Turistička organizacija Vojvodine, Bulevar Mihajla Pupina 6, 21000 Novi Sad, Srbija, Telefon: +381 21452 910, E-mail: nts.pavlovic@gmail.com

8 Prof. dr Ružica S. Kovač Pečkai Žnideršić, redovni profesor, Univerzitet u Novom Sadu, Ekonomski fakultet u Subotici, Segedinski put 9-11, 24000 Subotica, Srbija, Telefon: +381 24 628 134, E-mail: znikor@ef.uns.ac.rs

EP 2014 (61) 4 (837-849) 